\title{
磁気遅延素子を利用したディジタルフィルタ†
}

\author{
田所嘉 昭・樋口龍雄・穴山武 \\ 東北大学工学部 仙台市荒巻字青葉 \\ (昭和 47 年 8 月 3 日 受付)
}

\section{Practical Realization of Digital Filters Using Magnetic Delay Elements}

\author{
Yoshiaki Tadokoro, Tatuo Higuchi and Takeshi Anayama \\ (Faculty of Engineering, Tohoku University, Sendai) \\ (Received August 3, 1972)
}

\begin{abstract}
Many digital filters for process control systems are used in low frequencies. These are not. required to be very accurate, but only simple and handy. This paper describes a method for the construction of a digital filter suitable for an on-line process control environment. Magnetic elements are used as delay elements, which are the basic components of digital filters. The most important advantage of the magnetic delay element is the very long delay operation which is: possible. This allows filters for very low frequencies to be constructed easily, with a great reduction in size as compared to that of analogue filters. And also, the magnetic delay element has high reliability in a wide range of environmental conditions, and is capable of isolating the input circuits from the output circuits.

As an example, the first-order low pass filters are constructed by the impulse invariant way and the bilinear transformation. The characteristics of these filters are examined. Consequently, it is clear that the errors arising from elements are about $0.3 \%$, and these amplitude characteristics agree approximately with calculated results. In addition, the filter characteristics can readily be altered merely by changing the value of the coefficient or the sampling frequency.
\end{abstract}

\section{1. ま え がき}

ディジタルフィルタはアナログフィルタに比ベ, フ ィルタ特性の柔軟性, 急峪な周波数特性でも安定に実 現できること,インピーダンス整合の問題がないなど 多くの特長を有し，情報処理用あるいは制御用として 各方面で興味がもたれている. またその研究の進展も めざましいものがあり1) 4)，さらに多くの分野でディ ジタル化, サンプリング化が進んでいる現在, このデ イジタルフィルタはますます注目されてくると思われ る.

従来報告されているその構成法は, 電子計算機によ るものがほとんどである。これは高精度のディジタル フィルタを構成することができる反面, 現状では設備 費用が高いことやオンライン動作などに関して問題が

$\dagger$ 第 11 回計測自動制御学会学術講演会で発表 (昭 47.8)
あり ${ }^{5,6)}$ ，そのハードウェア化に対する研究が盛んに 行なわれている(1),2),4),5). そのさい, ディジタルフィ ルタはその動作上，低周波側での制限がないため，特 に抵抗やコンデンサなどの受動素子より構成されるア ナログフィルタに拈いては，大きなコンデンサの值を 必要とする低周波領域で有効であることが指摘されて いる5). その構成法としては，ディジタルフィルタの 動作を表わす差分方程式の計算を，ディジタルで行な ら方式とアナログで行なう方式に大別される゙7). 前者 はディジタル計算を行ならため AD-DA 変換器を必要 とし，その精度は計算の桁数を多くとることにより高 めることが可能である: 後者は入力のアナログ量のパ ルス列をそのまま使って計算が行なわれるため, その 構成は非常に簡単になる. 精度は使用する遅延, 乗算, 加算などのアナログ素子によって原理的に扣さえられ る. この両方式を $0.1 \sim 1 \%$ 程度の精度で比較すると, 
アナログ方式が構成が簡単でオンライン動作が容易に なると思われる。それゆえ一般にそれほど精度を必要 とせず，むしろ手軽さが要求される制御用ディジタル フィルタとしてはアナログ方式が適している：な特遅 延素子の伝達誤差がフィルタに拉よぼす影響について 恔文献 8) で述べられている。このアナログ方式で構 成されたフィルタとしては，コンデンサと演算増幅器 より構成される遅延素子を基本としたものがすでに報 告されている.この遅延素子はコンデンサの漏孔電荷 のため長時間遅延に適さず，低周波領域のフィルタ構 成要素としては問題があることが指摘されている ${ }^{9), 10)}$.

著者らがこれまで研究してきた磁気遅延素子は, 特 に長時間遅延に適し, 入出力端子の相互絶縁がとれる ため回路構成が簡単になる特長がある ${ }^{11)}$. そのためこ の磁気遅延素子は, 低周波領域の制御用ディジタルフ ィルタの基本構成要素として適しているととるに，こ のフィルタを簡単に構成する可能性を有していること が期待でさる。

本研究はこのような観点の下に行なわれたもので, もっとも基本となる 1 次のディジタルフィルタを Impulse Invariance と Bilinear 法1)によって設計し, 磁気遅延素子を用いて構成した. その結果, 構成が簡 単であること, 構成要素の誤差は $\pm 0.3 \%$ でその周波 数特性も汇計算值に一致することを確かめた. 特に 乙ゃ断周波数が約 $200 \mu \mathrm{Hz}$ の超低周波のブィルタに おいても安定に動作することが明らかになった。

\section{2. ディジタルフィルタの構成要素}

ディジタルフィルタに必要な構成要素は, 遅延素子, 乗算器, 加算器の 3 つの要素である. そのうちもっと も基本となるのが遅延素子である. ここではこの遅延 素子に磁気アナログ遅延素子を使用する. 以下，その 各構成要素がどのように構成されるかについて述べる. な拉，全体の構成をできるだけ簡単にするため，遅延 素子で構成されるシフトレジスタの部分にバイアス分 を加えて, 遅延素子を単極性とした。

\section{$2 \cdot 1$ 遅延素子}

磁心を利用して遅延素子を構成するとき, Fig. 1 亿

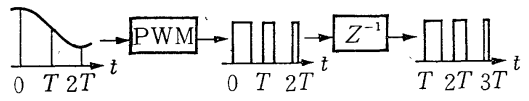

Fig. 1 Delay of pulse width

示すようにサンプリングされたアナログ信号を，いっ たんパルス幅変換器 (PWM) でパルス幅にし，その パルス幅となった信号を遅延させる方式が簡単で他の 回路を制御するにも都合がよい，遅延素子の原理を Fig. 2 に示す. いま図に示す七ステリシス上の正の 、飽和磁束レベルA を基準にしてこの動作を考える. 書 き込み回路を信号パルス幅 $T_{i}$ の期間だけ導通させる 之, 磁束レベルは基準の A 点より $\left(E_{W} / N_{W}\right) \cdot T_{i}$ だけ 変化し B点に移る.すなわちB点に信号が書き込まれ

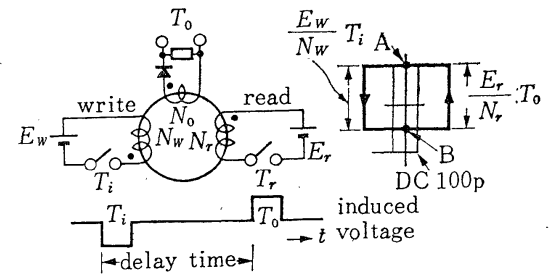

Fig. 2 Principle of magnetic delay element たことになる．この磁束レベルは外部より磁束変化を 起こすような作用を受けない限り, 磁心の記憶特性に より原理的に半永久に保持される. このことが磁心を 利用した磁気遅延素子が長時間遅延に適している理由 である，遅延時間たったのち読み出し回路を導通させ， もとのA点のほうに信号を読み出す。 このさい読み出 し回路の電源 $E_{r}$, 巻回数 $N_{r}$ をそれぞれ書き込久回 路の電源 $E_{W}$, 巻回数 $N_{W}$ に等しくして和けば, 読 み出し時の誘起電压のパルス幅 $T_{0}$ が入力信号 $T_{i}$ に 等しくなる. 実際の回路を Fig. 3 に示す. 電源には

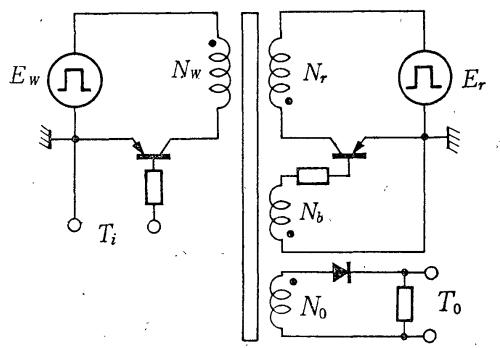

Fig. 3 Circuit of magnetic delay element パルス電源を使用し，雑音などにより回路が誤動作す， ることを防止している. また読み出し回路には正帰還 をかけて波形の立上りと立下りをよくしている。

いっぽう, パルス幅変換器も磁心を利用して構成す ることができる: その原理は注 Fig. 2 の遅延素子 の原理と同じである，ただし，この場合は書き込み回 路を閉じる期間を一定とし；書き込み回路の電源が入 力信号電圧となる.

\section{$2 \cdot 2$ 乘 算 器}

遅延されてくる信号に重みをかける乗算器の回路を Fig. 4 に示す. すなわち遅延素子の出力信号のパル ス幅 $T_{0}$ と係数 $a_{k}$ などに相当する電圧 $V_{a}$ との乗算 を行ない，信号をパルス面積 $V_{a} \cdot T_{0}$ (volt $\times \mathrm{sec}$ ) とす る.このように遅延素子の信号をパルス幅としたため 乗算器が簡単になった. な抗この乗算器のところで遅 延素子を単極性にするために入れたバイアス分が，バ イアス分に相当するパルス幅 $T_{B}$ によって除かれる. また 4 象限乗算は係数の符号により，トランジスタ $Q_{1}, Q_{2}$ を導通させる $T_{0}{ }^{\prime}$ と $T_{B}$ なるパルスを切り替 えて行なわれる.

\section{$\mathbf{2 \cdot 3}$ 加 算 器}

加算器としては, 演算増幅器を使用して Fig. 5 に 


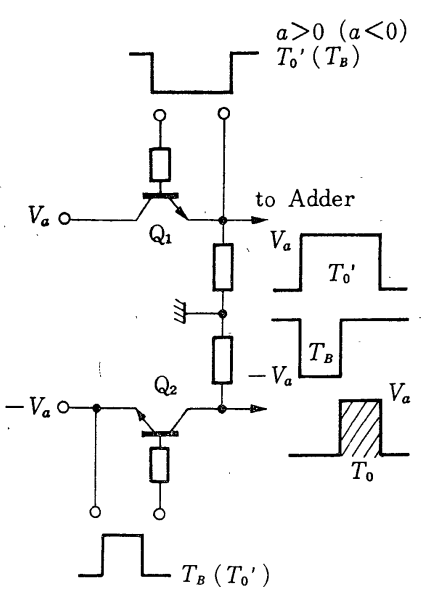

Fig. 4 Multiplier

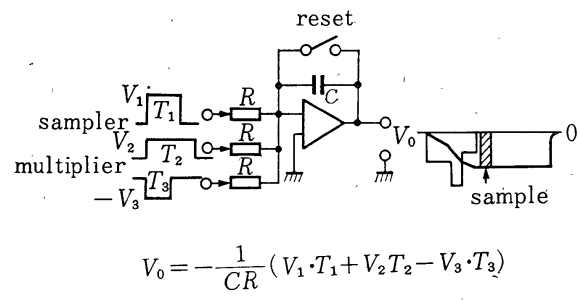

Fig. 5 Adder using operational amplifier

示すよらに加算積分器を構成した。 ここではサンプラ, 乗算器からのパルス面積の信号を加算積分し，その值 を次の入力信号が入るまでホールドする，そして入力 信号が入る直前にリセット回路によってリセットされ る.な扮加算動作が終了した直後跑の結果はサンプ リングされて，フィルタの計算に使用される．そのと きのサンプラ回路としては Fig. 6 に示す回路を使用 した.

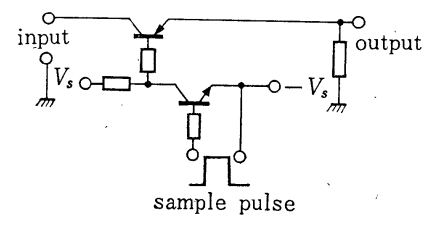

Fig. 6 Sampler circuit

\section{1 次のディジタルフィルタの 具体的構成法}

ここでは 1 次のディジタルフィルタを例にとって, Impulse Invariance と Bilinear 法によってフィルタ を設計し, その具体的溝成法を述べる. 2 次以上の構 成はこれに遅延素子と乗算器を增加させていけばよい，

Impulse Invariance 法によるディジタルフィルタ は, アナログフィルタの伝達関数を標準 $Z$ 変換するこ とにより（1）式によって与兄られる.

$$
H(s)=\frac{\omega_{c}}{s+\omega_{c}} \longrightarrow H(Z)=\frac{\omega_{c}}{1-e^{-\omega_{c} T_{s}} Z^{-1}}=\frac{\omega_{c}}{1-b_{1} Z^{-1}}
$$

ただし，

$$
b_{1}=e^{-\omega_{c} T_{s}}
$$

(1) 式は Fig. 7 のブロック線図で構成され, その振 幅特性は（3）式で表わされる.

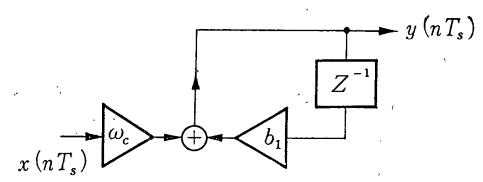

Fig. 7 Block diagram of $\omega_{c} /\left(1-b_{1} Z^{-1}\right)$

$$
\left|H\left(\varepsilon^{j \omega T_{s}}\right)\right|=\left|\frac{\omega_{c}}{1-b_{1} \varepsilon^{-j \omega T_{s}}}\right|=\frac{\omega_{c}}{\sqrt{1+b_{1}^{2}-2 b_{1} \cos \omega T_{s}}}
$$

いっぽう, Bilinear 法によるディジタルフィルタは, 連続系の伝達関数より（4)，（5）式の関係を使って 求められ (6) 式で表わされる.

$$
\begin{gathered}
\nu_{c}=\tan \left(\omega_{c} T_{s} / 2\right) \\
S=(Z-1) /(Z+1) \\
H(s)=\frac{\omega_{c}}{S+\omega_{c}} \rightarrow H^{\prime}(s)=\frac{\nu_{c}}{S+\nu_{c}} \rightarrow H(Z) \\
=\frac{\nu_{c}}{\frac{Z-1}{Z+1}+\nu_{c}}=\beta \frac{1+Z^{-1}}{1-b_{1} Z^{-1}}
\end{gathered}
$$

ただし，

$$
\beta=\nu_{c} /\left(1+\nu_{c}\right), \quad b_{1}=(1-2 \beta)
$$

(6) 式は Fig. 8 のブロック線図で構成され, その振 幅特性は（8）式で示される.

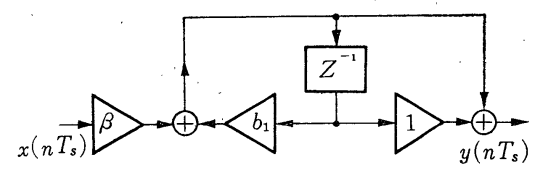

Fig. 8 Block diagram of $\beta\left(1+Z^{-1}\right) /$

$$
\left(1-b_{1} Z^{-1}\right)
$$

$$
\left|H\left(\varepsilon^{j \omega T_{s}}\right)\right|=\beta\left|\frac{1+\varepsilon^{-j \omega T_{s}}}{1-b_{1} \varepsilon^{-j \omega T_{s}}}\right|=\beta \sqrt{\frac{2\left(1+\cos \omega T_{s}\right)}{1+b_{1}^{2}-2 b_{1} \cos \omega T_{s}}}
$$

2. で述べた構成要素を用いた 1 次のディジタルフ ィルタの全体の構成図を Fig. 9 に示す. この図に括い

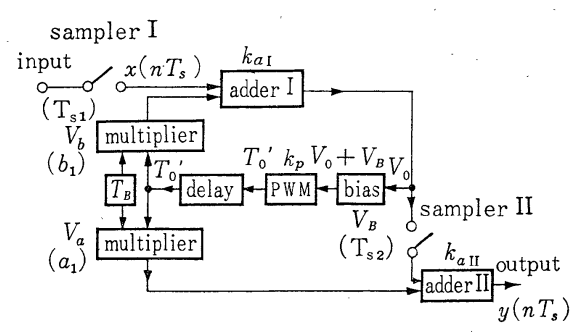

Fig. 9 Block diagram of first-order digital filter using magnetic delay element 
て係数 $a_{1}, b_{1}$ の值を適当に選ぶことによって，Fig. 7, Fig. 8 のフィルタが実現できる. サンプラ I，IIには 洏極性の Fig. 6 亿示す回路を使用し, 遅延素子の注 うを単極性にするため，PWM の前段にバイアス電圧 $V_{B}$ を入れてある．前述したように，このバイアス分 甠乗算器のところで $T_{B}$ なるパルスによって除かれ る. またこのバイアス分で遅延素子，PWM などの特 性の不感帯部分の影響も除かれる. 加算器はホールド 回路の役目もか叔る.

荷重俰数 $a_{1}, b_{1}$ 、 飞相当する係数電圧 $V_{a}, V_{b}$ の設定 は，この装置に扔いては（9)，(10）式によって決め られる。

$$
\begin{aligned}
& b_{1}=\left(T_{0} V_{b} k_{a I} k_{p}\right) / T_{0} \longrightarrow V_{b}=b_{1} /\left(k_{a I} k_{p}\right) \\
& a_{1}=\left(V_{0} k_{p} V_{a}\right) /\left(T s_{2} V_{0}\right) \longrightarrow V_{a}=\left(a_{1} T_{s 2}\right) / k_{p}(10)
\end{aligned}
$$

ただし， $k_{a I}$ : 加算器 $\mathrm{I}$ の変換係数, $k_{p}: \mathrm{PWM}$ の変 換係数, $T_{s 2}$ : サンプラ II 導通期間

この装置は Fig. 10 そ示す A,〜,E の5つのパル

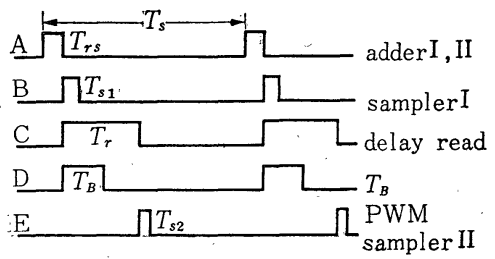

Fig. 10 Time chart for operation of Fig. 9 スによって動かされる.まずAのパルスで加算器 I I I ルホールドされている電圧がリセットされる. 次いで Bのパルスでサツプラ I が働らき， 入力信号 $x(t)$ が サンプリングされて $x(t) T_{s 1}$ なるパルス面積になる. いっぽう，Cのパルスによって遅延素子から読み出さ れた $T_{0}{ }^{\prime}$ なるパルス幅は,バイアス分を除くDのパル スによって差し引かれ信号パルス幅 $T_{0}$ となる．この 信号に係数 $b_{1}$ のかかった $V_{b} T_{0}$ なるパルス面積と入 カサンプラからの $x(t) T_{s 1}$ なるパルス面積が加算器 I により加算される. その結果は PWM の入力とサン プラ II 入力そなる. そしてEのパルスによってサン プラ II と. PWM のサンプラが導通する. 加算器 II で は，このサンプラ【による $V_{0} T_{s 2}$ と乗算器からの $V_{a} T_{0}$ なるパルス面積が加算されて出力信号となる。 計算に必要な時間は Fig. 10 からわかるように (11) 式で表わされる。

$$
T_{c a l}=T_{r s}+T_{r}+T_{s 2}
$$

サンプリング周期 $T_{s}$ の $T_{c a l}$ 以外の期間には, 信号 梳々の記憶特性が半永久的である磁気遅延素子に記憶 されている，そのため $T_{s}$ を大きくしてもその計算の 精度には影響を与えない.

\section{4. 実 験 結 果}

実験は遅延素子，PWM に Table 1 に示す特性の 磁心を使用し, Table 2 に示す回路条件のもとに室温 で行なった。
Table 1

Property of $\mathrm{Mn}$ Mg Ferrite core*

\begin{tabular}{c|c}
\hline items & values \\
\hline$\phi_{m}$ & $1.8 \mu \mathrm{Wb}$ \\
$\phi_{m} / \phi$ & $95.7 \%$ \\
$(10 \mathrm{AT})$ & $91.9 \mathrm{AT} /$ \\
$H_{c}$ & $\mathrm{~m}$ \\
\hline
\end{tabular}

Table 2 Experimental conditions

core $\operatorname{size}(11 x$

$8 \times 4) \mathrm{mm}$

1. で述べたように，ディジタルフィルタの動作を 表わす差分方程式をアナログ計算することにより実現 されたディジタルフィルタの精度は，構成要素の精度 で原理的に捛さえられる，そして，その各構成要素の 精度が全体のフィルタ特性に尔よぼす影響についての 具体的検討は重要な問題であるが，これについては稿

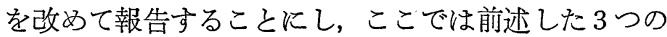
構成要素の精度と，それによって構成されたフィルタ の振幅特性がどの程度計算に一致するかを示すにとど める.

\section{1 構成要素の誤差と装置の負荷特性}

2. で述べた構成要素の精度を調べるため, Fig. 7, Fig. 8 のフィルタが構成されるときのよ5に各構成 要素を直列に接続して，その誤差を測定した．湘定系 のブロック線図と測定条件を Fig. 11 に示す. Fig. 12 は係数電压 $V_{b}$ を $7 \mathrm{~V}$ とし, 乗算器への入力パル

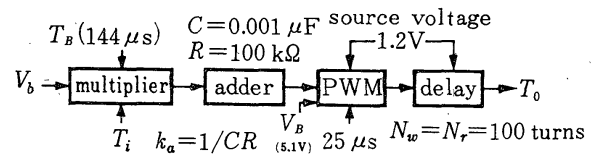

Fig. 11 Measurement circuit for element accuracy

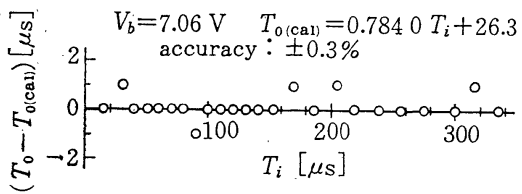

Fig. 12 Measurement result of Fig. 11

ス幅 $T_{\text {々 }}$ と遅延素子の出力パルス幅 $T_{0}$ との関係を測 定した結果の一例である. 入力パルス幅 $80 \mu$ S と 237 $\mu \mathrm{s}$ より求めた計算式に対する誤差は約 $\pm 0.3 \%$ であ る. $V_{b}$ が $3 \mathrm{~V}, 5 \mathrm{~V}$ の場合も同様な精度を示した. また $T_{i}$ を一定とし $V_{b}$ を変化させたときの $V_{b}$ と $T_{0}$ の関係も上記の精度内に物さまった.

Fig. 13 は Fig. 9 に示した装置の出力電圧と負荷 電流との関係を示す.これはこのフィルタを綎続接続 するときや，他の回路と接続するとき問題になること である. $C, R$ などより構成されるアナログフィルタ の場合は，このインピーダンス整合が大きな問題とな っている. 本実験の方式では, この負荷電流は加算器 


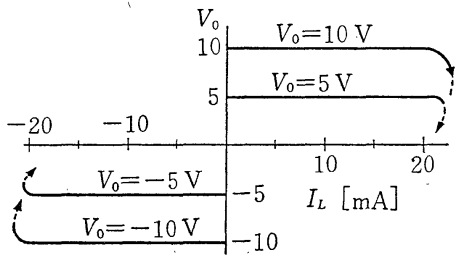

Fig. 13 Output voltages versus load currents

として使用した演算增幅器の負荷特性によって決まり, 現在の装置では約 $20 \mathrm{~mA}$ までとることができる.

\subsection{Impulse Invariance 法によるフィルタ}

Fig. 9 に扔いて $a_{1}=0$ とすると Fig. 7 で示した ディジタルフィルタが実現できる.（2）式からわか るよう飞係数 $b_{1}$ 拈よびサンプリング周期 $T_{s}$ を変化 させることによって，このフィルタのしゃ断周波数 $f_{c}$ が変化できる. Fig. 14 は $T_{s}$ を一定として $b_{1}$ を 変化させた場合，Fig. 15 は $b_{1}$ を一定として $T_{s}$ を

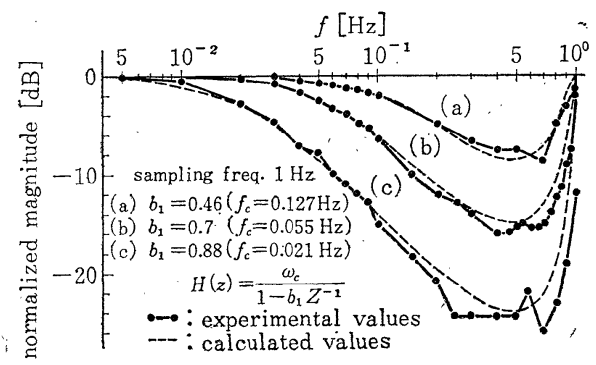

Fig. 14 Magnitude versus frequency of $\omega_{c} /\left(1-b_{1} Z^{-1}\right)$

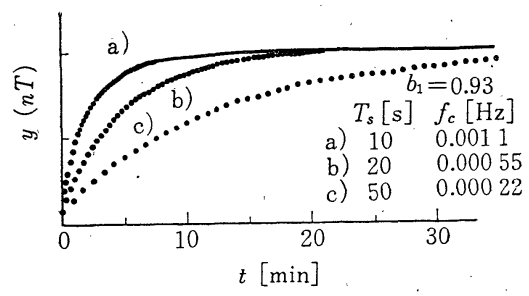

Fig. 15 Step responses of $\omega_{c} /\left(1-b_{1} Z^{-1}\right)$

変えた場合である. Fig. 14 の振幅特性は $T_{s}=1 \mathrm{~s}$ と して，出力を記録計に觉がかせて測定を行なった：実 線が実験值で点線が ( 3 ) 式から求るる計算值である. 注涪計算值とあっていることがかかる。同図に执いて サンプリング定理を満足しない $0.5 \mathrm{~Hz}$ 以上の周波数 に対して，再び振幅が大きくなってくるのは aliasing 効果7)のためである.これはディジタルフィルタの前 段にローパスのアナログフィルタを入れることによっ て除かれる.

Fig. 15 は $b_{1}=0.93$ とし， $T_{s}$ を变えてこのフィル タのステップ応答をとったものである. この図より理 解されるように $T_{s}$ を大きくすることにより，乙中断 周波数の非常に低いフィルタが実現できる，たとえば
$T_{s}=50 \mathrm{~s}$ とするとしゃ断周波数は約 $200 \mu \mathrm{Hz}$ となる このしゅ断周波数をアナロダフィルタで実現するとな ると， $1 \mathrm{M} \Omega$ の抵抗（アナログフィルタでは他の回路 との接続の関係上，この抵抗をあまり大きくすること ができない）を使用したとさでさ光，約 $1000 \mu \mathrm{F}$ と 非常に大きなコンデンサの值が必要になる．このこと は低周波領域でのディジタルフィルタの有効性を示し ている.

Fig. 16 は $0.01 \mathrm{~Hz}$ の信号に同じ振幅の $29 \mathrm{~Hz}$ の

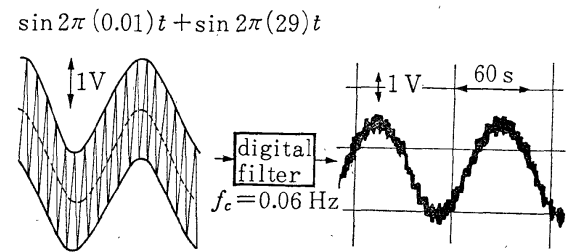

Fig. 16 Filter effect of digital filter $\omega_{c} /\left(1-0.7 Z^{-1}\right)$

雑音がのった波形を, Fig. 7 で $f_{c}=0.06 \mathrm{~Hz}$ のフィ ルタを実現して雑音を除いた結果である.

\subsection{Bilinear 法によるフィルタ}

この場合の振幅特性は（8）式からもわかるように, $2 \pi f \cdot T_{s}=\pi$ で振幅が零になる。それゆえたとえばサ ンプリング周波数 $f_{s}$ を $100 \mathrm{~Hz}$ にえらべば， $f=50$ $\mathrm{Hz}$ のとさ振幅は零になる。測定系などでよく起る問 題である商用周波数 $50 \mathrm{~Hz}$ が雑音としてはいってし まうような場合このフィルタを使用すれば $50 \mathrm{~Hz}$ 除くことができる.そこでここでは $f_{s}=100 \mathrm{~Hz}$ とし た場合を例にして実験結果を示す。

Fig. 9 亿扔いて $a_{1}=1$ にする之 Fig. 8 のフィル タが実現できる. $f_{s}=100 \mathrm{~Hz}$ として你数 $b_{1}$ により $f_{c}$ を変化させて振幅特性をとった結果を Fig. 17 亿示

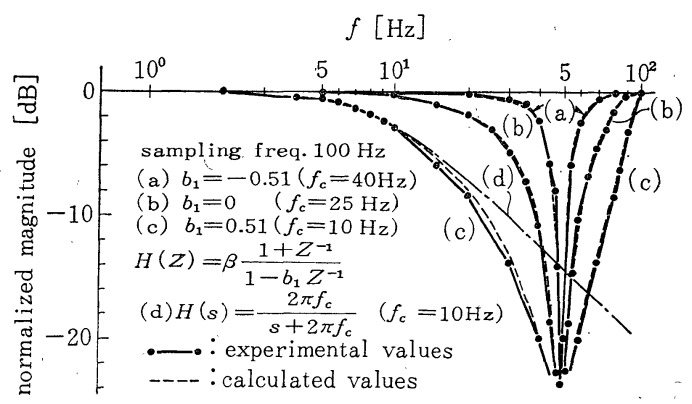

Fig. 17 Magnitude versus frequency of $\beta\left(1+Z^{-1}\right) /\left(1-b_{1} Z^{-1}\right)$

す. 測定はシンクロスコープ上で行なった. Fig. 14 と同様,計算値とよい一致を示している.な特 $b_{1}=0$ の 場合, このフィルタは帰還系を有さない nonrecursive 形を示す，他の場合は㷌還系を有する recursive 形 である.

Fig. 18(a) は振幅 $2 \mathrm{~V}, 1 \mathrm{~Hz}$ の信号に振幅 $3 \mathrm{~V}$, 

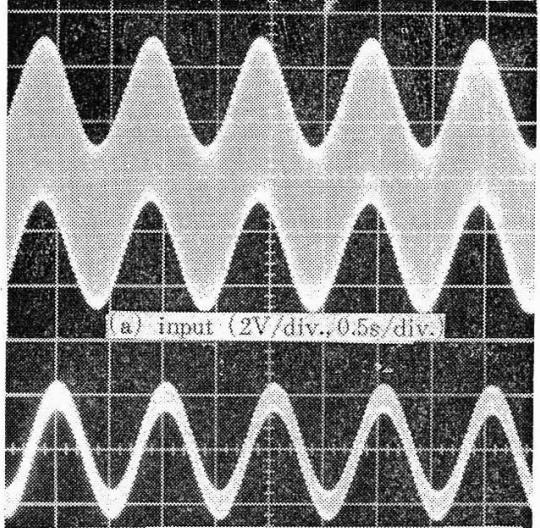

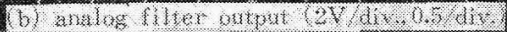

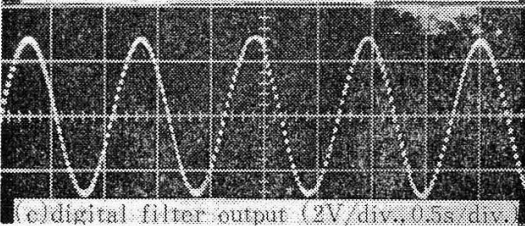

Fig. 18 Comparison between analog filter digital filter having same cut-off frequency $10 \mathrm{~Hz}$

$50 \mathrm{~Hz}$ の雑音がのった波形を表わす．これを Fig. 17 （d）に示す $f_{c}=10 \mathrm{~Hz}$ の1次のアナログフィルタに か将た場合之, 同じ $f_{c}$ をつ Fig. 17(c) の1次 のディジタルフィルタにか惊た場合の出力波形を兑机 ぞれ Fig. 18（b)，(c) に示す。この図より明らかな ように; ディジタルフィルタに扔いては $50 \mathrm{~Hz}$ がほ ぼ完全に除かれていることがわかる.

\section{5. ま と め}

制御用のディジタルフィルタとして, 磁気遅遈素子 を用いて1次のディジタルフィルタを構成し，その特 性を検討した。

その結果, 構成要素の誤差は約 $\pm 0.3 \%$ であり, そ のフィルタの振幅特性もほ添計算值に一致した．特に
アナログフィルタでは大きなコンデンサの值を必要と するので問題とされている低周波領域に执いても，碳 気遅延素子の特性上, 安定に動作することが確かめら れた。そこてこの構成法は簡単であり制御用のディジ タルフィルタとして, 手軽にオンライン動作させて使 用さ机ることが期待できる。

な特このフィルタの総合誤差の評価は, 回路傋成上 原理的に生ずる誤差と具体的な構成に起因して生ずる 誤差との検討ののちになされるべきで，この点に関し ては今後検討していきたい。

\section{参 考 文 献}

1) C.M.Rader \& B.Gold:Digital Filter Design Techniques in the Frequency Domain, Proc. IEEE, 55-2, 149/171 (1967)

2) L. B. Jackson et al. : An Approach to Implementation of Digital Filters, IEE Trans. AU-16-3, 413/421 (1968)

3) "Special Issue on Digital Filtering" IEEE Trans., AU-18-2 (1970)

4) L.R. Rabiner : Recursive and Nonrecursive Realizations of Digital Filters Designed by Frequency Sampling Techniques, IEEE Trans. AU-19-3, 200/ 207 (1971)

5) B. Gold, C.M. Rader:Digital Processing of Signals, McGraw Hill (1969)

6）伊详：ディジタルフィルタ技術の可能性と問題点, NHK 技術研月報，14,4-5，(1971)

7) D. J. Nowak, P. E. Schmid : Introduction to Digital Filters, IEEE Trans., 'EMC-10-2, 210/219 (1968)

8）二宮：サンプル值フィルタの誤差について，電子通信 学会論文誌，54-A-12，663/670 (1971)

9) W.Kuntz: A New Sample-and-hold Device and Its Application to the Realization of Digital Filters, Proc. IEEE, 56, 11, 2092/2093 (1968)

10) G.S.F. Orsten : An Analog Shift Register, The Review of Scientific Instruments, 41-7, 957/959 (1970)

11）田所・穴山：プリセット方式を用いた磁気フナログシ フトレジスタ，計測自動制御学会論文集，8-4，431/439 (1972) 